\title{
Ecological zonation of gastropods in the Matutinao River (Cebu, Philippines), with focus on their life cycles
}

\author{
K. Bandel ${ }^{1}$ \\ F. Riedel ${ }^{2}$
}

Keywords: tropical river, fluvial gastropods, ecology, distribution, ontogeny, protoconchs

The tropical Matutinao River was investigated to study factors determining the distribution of the extant gastropods. Since ecological zonation and life-cycles are somewhat correlated, we followed both research avenues and in particular focused on early ontogenetic strategies, discriminated by detailed studies of corresponding shell features. Twenty-six gastropod species, almost all of which are distributed over whole Cebu Island, occurred in the small Matutinao River. The specific associations of river sections, and ecological demands and life-cycles of gastropods are characterized. Of special interest are planktotrophic neritoidean larvae, which are usually carried to the sea and develop in the marine environment, but in rare cases remain and successfully metamorphose in freshwater. The biogeographic background and evolutionary consequences of the results are discussed.

\section{Zonation écologique et cycles biologiques des gastéropodes de la rivière Matutinao (Cebu, Philippines)}

Mots clés : rivière tropicale, gastéropodes fluviatiles, écologie, distribution, ontogénèse, protoconques

La rivière tropicale Matutinao a été étudiée quant à la question : qu'est-ce qui détermine la distribution des gastéropodes ? Comme la zonation écologique et les cycles sont parfois corrélés, nous avons suivi deux voies de recherches et, en particulier, concentrées sur les stratégies ontogéniques primitives qui peuvent être mises à jour à l'aide de l'étude détaillée des caractères des coquilles. Avec 26 espèces de gastéropodes, presque toutes les espèces qui sont distribuées sur toute l'île Cébu cohabitent dans la petite rivière Matutinao. Les associations de gastéropodes des sections de rivière, leurs besoins écologiques et les cycles biologiques des espèces sont précisés. D'un intérêt particulier sont les larves planctoniques de Neritidae qui sont normalement entraînées à la mer où elles se développent ; mais dans des cas rares elles peuvent rester et se métamorphoser avec succès en eau douce. L'analyse biogéographique et évolutive des résultats est discutée.

\section{Introduction}

The theoretical background on which this paper is based involves a number of research avenues such as systematics and biogeography, historical geology, evolutionary ecology, developmental biology, limnology and also biological oceanography.

\footnotetext{
1. Universität Hamburg, Geologisch-Paläontologisches Institut und Museum, Bundesstr. 55, D-20146 Hamburg, Germany.

2. FU Berlin, Institut für Paläontologie, Malteserstr. 74-100, D12249 Berlin, Germany.
}

The focal points, however, which are dealt here with, can be derived from a single question : what determines the distribution of gastropods in a river? We regard to study the way in which ontogenies are developed to represent the best source of information to understand the potential of a species to colonize a river. In subsequence, the zonation of the corresponding organisms is controlled by their aut- and synecology. Consequently, with regard to the crucial question, we focused on life-cycles and ecological zonation and investigated the gastropod fauna of a tropical river in which biodiversity is adequately high.

The Matutinao River is such a case. It flows in the southwest of Cebu Island and empties into the Tanon 
Strait, which separates Cebu from the neighbouring Negros, both islands belonging to the Visayas, which constitute the central Philippines (Fig.1). The river is named after a small village located near its estuary. The Matutinao River with its Kawasan Falls and framing tropical vegetation represents a natural reserve of Cebu Island. Pollution is here quite low, which is in contrast to most other rivers of the island. Judging from the geological setting (compare Wolcke 1991), the river may have begun to form about 120.000 to 130.000 years ago and since then developed its present morphology. Almost thirty different gastropod species have colonized the Matutinao River and constitute specific associations that are characteristic of the different sections, which will be introduced below.

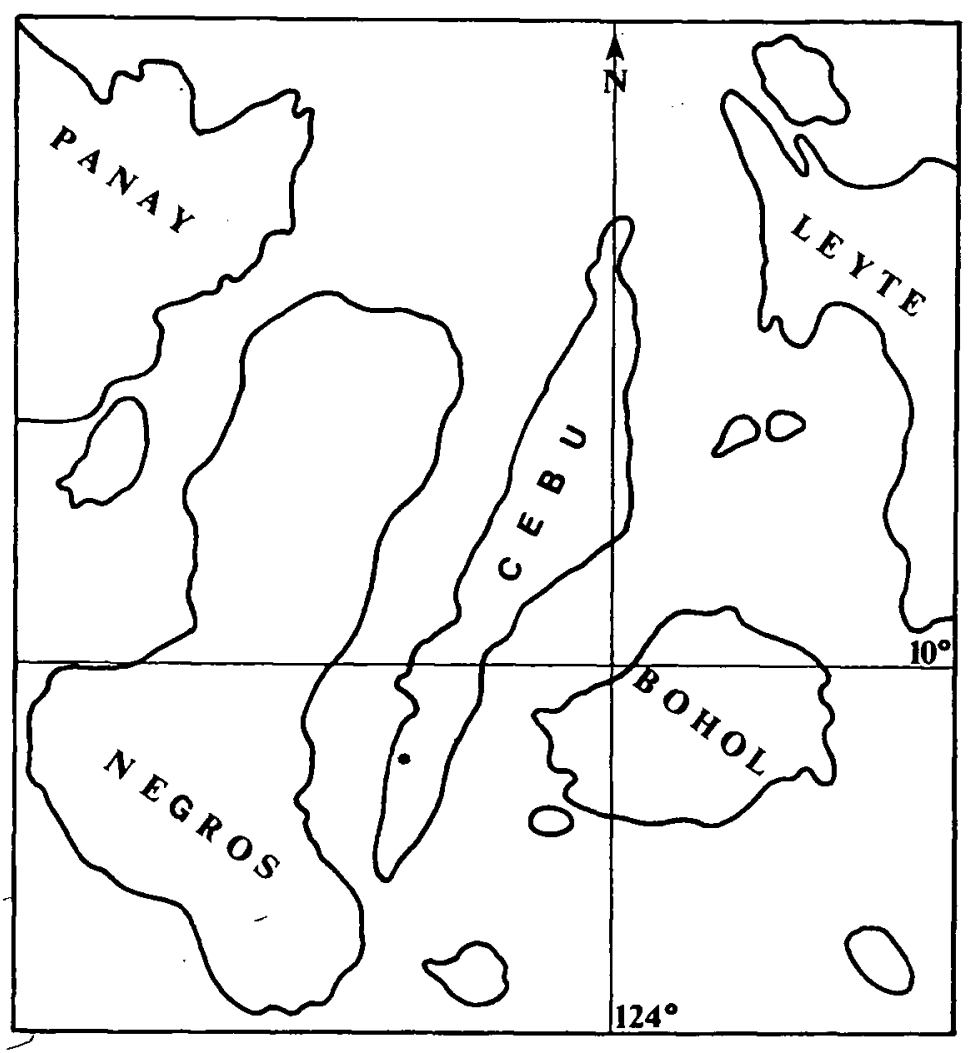

Fig.1. Central Philippines with Cebu Island and location of the Matutinao River (*). Not to scale.

Fig. 1. Philippines centrales : emplacement de l'île Cebu et de la rivière Matutinao $(*)$.

The taxonomy of corresponding species suffers from a certain lack of documentation in the relevant literature i.e. there exist no modern systematic papers which treat the freshwater (and brackish water) gastropod fauna of the Philippines at species level. Classical descriptions such as published by Quadras \& Moellendorff $(1894,1895)$ have been succeeded by a number of publications (among others Abbott 1948, 1951, 1958). Burch (1980) provided a classification of most genera, and in fact, when considering the Indo-Pacific scale for comparison (Indo-Australian archipelago :
Ancey 1898, Rensch 1934, Riech 1937, Benthen Jutting 1956, 1959 ; Thailand : Brandt 1974; Taiwan : Pace 1973 ; Fiji and other Pacific islands : Haynes 1985, 1990 ; Starmühlner 1976, 1993), it appears that taxonomy at generic level is fairly well established. The question of distribution, however, can be only resolved at the species level. Here we were faced with the problem mentioned above that many data from the literature are difficult to reproduce. In particular, taxonomy was usually based upon teleoconch (postmetamorphotic shell) characters of the gastropods, and only now and then supported by some, often quite insufficient anatomical data (but see Haynes 1991, 1996, for Septaria). In consequence, species diversity of each area that has been investigated by the various authors can be sketched, however, on the larger biogeographic scale it is momentary quite impossible to decide if certain individuals of a genus from one place represent the same species occurring in a second or third place. Since we are not dealing with species of the other areas here, we attach the main importance to the fact that we are able to distinguish the gastropod species of the Matutinao River. The biogeography of involved species must there fore remain of secondary importance. We do not intend to increase the corresponding chaos and therefore add in our taxonomy in several cases the supplements cf., aff. or even indet. to the species and genus respectively. We thus do not pretend to have a clear picture about the status of such species, which usually does not exist.

The potential of dispersal of fluvial gastropods is particularly controlled by the feeding strategy during early ontogeny, which may be roughly discriminated in planktotrophy and lecithotrophy. These strategies are clearly documented in certain shell features which are formed during early ontogeny. Vice versa the detailed investigation of protoconchs (premetamorphotic shell) provides the important information whether a species dispersed via a free-swimming marine larva or whether it crawled off its spawn or mother. Due to the fact that poecilogony (different early ontogenies within a single species) has not been documented without doubt in any known shelled gastropod (see Bandel 1975, Hoagland \& Robertson 1988, Bouchet 1989, Bandel et al. 1997a), different protoconch-types are currently used for taxonomy at the species level. The distribution of some of the gastropods in the Matutinao River, however, forces us to conclude that intraspecific ontogenetic differences actually occur (see below), and this is of major importance for evolutionary and ecological concepts. 


\section{Material and methods}

The Matutinao River was investigated by us in February 1994 . We walked up and down within the river four times, mapping the distribution of gastropods and collecting specimens. Living species were not only observed in the field but also taken to the University of San Carlos (Cebu City) and here studied in detail using a binocular microscope. This accounts especially for the embryos which were extracted from spawn, brood pouches of thiarids and the uterus of Bellamya. A representive number of all species was fixed in $70 \%$ ethanol with regard to some anatomical recheck which was conducted in Hamburg and Berlin. The radulae of most species, and shells of hatchlings and juveniles were mounted on stubs, sputtered with gold and examined using a scanning electron microscope (CamScan and Cambridge).

Voucher material is deposited at the GeologischPaläontologisches Institut und Museum of the University of Hamburg.

\section{Results}

\subsection{Environmental setting}

The Matutinao River has cut its bed into the soft Carcar Limestone, which had been deposited in Plio-Pleistocene times (Büchsel 1991), and is only partly filled with gravel and sand. Upstream, the wooded flanks increase in steepness and finally there is a narrow gorge (Fig. 2). A strong spring (Fig.2:2) that issues from an extended subsurface cave system in the limestone supplies the river with water throughout the year. Close to the spring two intermittent streamlets join, which canalize water only in the rainy season and otherwise dry out or form a chain of more or less isolated pools (Fig. $2: 1$ ). This pool-creek-section lies in the narrow gorge that ends in a cave, which represents the uppermost point of our investigations. Right below the spring a small artificial lake has been created in order to supply a power station (Fig. $2: 4$ ) continuously with a portion

Fig.2. Sketch of the Matutinao River (Cebu Island, Philippines). Numbers indicate ecologically characteristic sections which are referred to in the text. The dotted lines indicate the 100 meter contour line. Scale as indicated. Additionally distances in $\mathrm{km}$ are directly marked by the numbers $0.5,1.0,1.5$ and 2.0 .

$1=$ intermittent creek with pools ; $2=$ spring and artificial lake ; $3=$ Kawasan Falls ; $4=$ power station ; $5=$ estuarine transition ; $6=$ river mouth

Fig. 2. Carte de la rivière Matutinao. Les nombres 1 à 6 indiquent les différentes caractéristiques écologiques des 6 sections étudiées. En pointillé : courbes de niveau de $+100 \mathrm{~m}$.

Les distances à l'embouchure notées par les chiffres $0.5,1.0,1.5$ et 2.0 sont en $\mathrm{km}$.

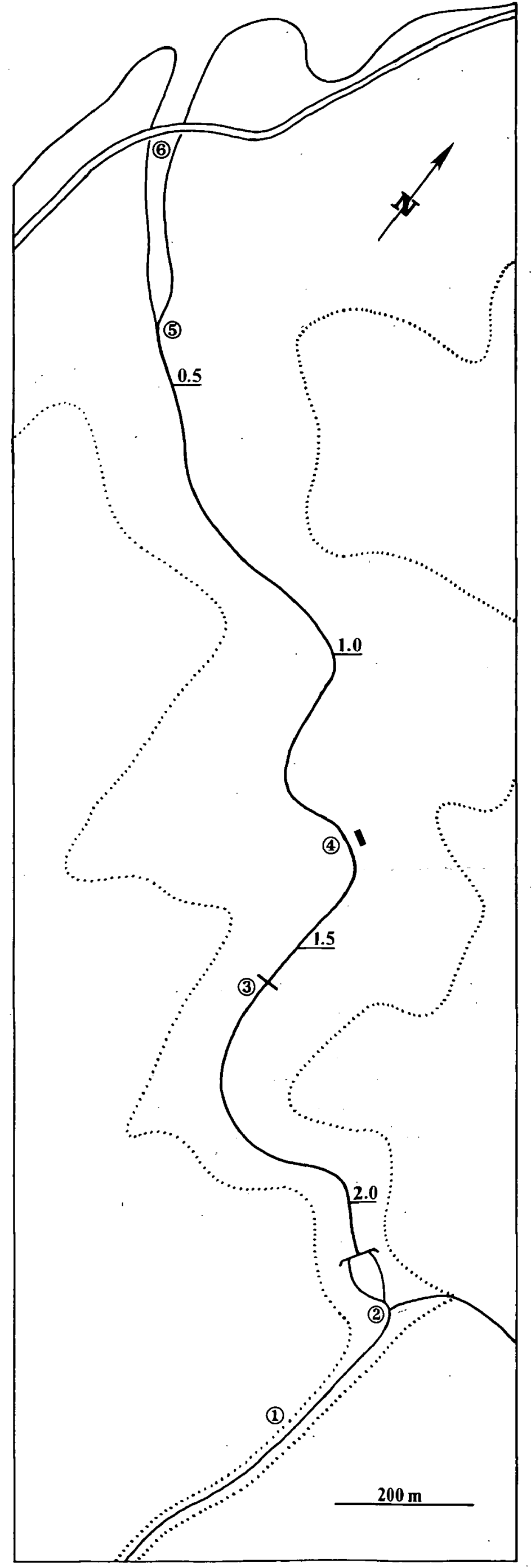


of the river water via a pipeline. The dam of this lake provides an artificial fall from which the remaining water makes its way to the natural Kawasan Falls (Fig. $2: 3$ ). There are actually two main waterfalls, with the lower one creating a comparatively large pool, which is used i.e. by tourists for swimming. Downstream there are no more falls but several rapids. At the power station, the water which originates from the artificial lake, flows down a steep ramp and joins the river. Further downstream, large boulders dominate the river bed for about $\mathbf{4 0 0}$ meters. The lowermost freshwater section is characterized by a long narrow island, which terminates right in front of the estuary (Fig. $2: 5$ ). In this portion of the river sandy areas of significant size appear. The uppermost occurrence of Nipa palms at the transition to the island reflects the daily highstand of tides. In this upper part of the estuary salinity has a very limited influence, while the actual river mouth (Fig. $2: 6$ ) is almost fully marine at high tide, and at least brackish if not fresh when the tide is low.

The water of the Matutinao River is rich in calcium carbonate, and very clear, except for the actual river mouth, and thus usually well permeable to light. Vegetation is mostly shading the river quite well, however, there exist a fair amount of places and sections where solar radiation has full impact. Pollution was limited (in 1994!) and almost exclusively originated from some local people washing clothes. The water temperature varies in a narrow range around $26^{\circ} \mathrm{C}$ throughout the year. Most portions of the Matutinao river are quite shallow and can be explored by walking within the water. The artificial lake and the pools of the Kawasan Falls are several meters deep, which accounts also for the estuary, i.e. at high tide. The current pattern of the river may be complex and places with countercurrents or slack water are not rare. In general, the water flows with a speed between 5 and $15 \mathrm{~km} / \mathrm{h}$. Seasonal differences can be neglected.

Aside from gastropods the macrofauna was dominated by large shrimps, which occurred most frequently within the artificial lake, and to some smaller fish entering the estuarine section.

\subsection{Ecological zonation and ontogeny}

Notes : The listing of associated gastropods refers to populations. Freshly metamorphosed juveniles e.g., which settle in the estuary and then all migrate upstream are not listed for the estuary. It is referred to the descriptions of specific life-cycles to get the complete picture.

The taxonomic status of species and authorship of taxa is only indicated when first mentioned. We prefer to describe ecological characteristics in the past tense because pollution may have increased during the last four years and specific associations correspondingly changed.

\section{POOL-CREEK SECTION}

\section{Associated gastropods :}

Superfamily Ampullarioidea GRAY, 1824

Family Viviparidae GRAY, 1847

Subfamily Bellamyinae RÖHRBACH, 1937

Genus Bellamya Jousseaume 1886 with a species indet.

Superfamily Cerithioidea FÉRUSSAC, 1819

Family Thiaridae TrosCHEL, 1857

Subfamily Thiarinae TroSCHEL, 1857

Genus Tarebia H. \& A. ADAMS, 1854 - with T. cf. granifera (LAMARCK, 1816)

?Subfamily Pachychilinae TrosCHEL, 1857

Genus Brotia H. ADAMs, 1866 - with $B$. aff. costula (Rafinesque, 1833).

Superfamily Lymnaeoidea RAFINESQUE, 1815

Family Lymnaeidae RAFINESQUE, 1815

Subfamily Lymnaeinae RAFINESQUE, 1815

Genus Radix MONTFORT, 1810 - with $R$. cf. quadrasi (MOELLENDORF, 1898)

Superfamily Planorboidea RAFINESQUE, 1815

Family Planorbidae RAFINESQUE, 1815

Subfamily Planorbinae RAFINESQUE, 1815

Genus Gyraulus AGASSIZ, 1837 - with $G$. cf. chinensis (DUNKER, 1848)

Ecological characteristics : Bellamya (Fig. 3 A-D) formed the densest population in this portion of the river. Individuals grazed on algal growth within the pools and filtered phytoplankton from the slowly flowing to stagnant water. They thus behaved like their close relative Viviparus MONTFORT 1810. Tarebia (Fig. 3 L-N, Fig. 4 A-B) and Brotia (Fig. 3 I-K) occurred in significant lower numbers of specimens and browsed on rocks i.e. in places where some water current was present.

Gyraulus (Fig. 3 E-G) and Radix (Fig. $3 \mathrm{H}$ ) were found exclusively in this section, the former particularly in the shallower pools with stagnant water. Radix moved also along the transitions between pools where moderate currents occurred. Both basommatophoran pulmonates were found to be attached to rocky substrate or plants, or drifted on the water surface respectively: Gyraulus apparently collected detrital material, while Radix fed on algae and other water plants. The 
pool-creek section represented the only portion of the river where the water temperature with up to $30^{\circ} \mathrm{C}$ was significantly higher than the usual $26^{\circ} \mathrm{C}$. The narrow gorge prevented direct sunlight to penetrate the water.

Life-cycles : The female of Bellamya is viviparous and dissection of the oviduct exhibited about twenty egg capsules, each containing a single embryo. The capsules represent thin-walled, whitish-transparent sacs of different sizes correlated with the sizes of the corresponding embryogenetic stages. Fresh eggs and little developed embryos have small egg capsules, later stages larger ones, due to the uptake of water into the capsule liquid. The embryos within the uterine tract may be lined up to form an ontogenetic sequence of significant length, from the cleaving zygote to minature adults which bear shells of up to four and a half whorls. Regarding the soft body, the embryogenetic development of Bellamya very closely resembles that of Viviparus and it can referred to the corresponding literature (e.g. Bandel 1982, Riedel 1993, and references therein). The early ontogenetic shell of Bellamya, however, can easily be distinguished from that of Viviparus. The initial whorl of Bellamya measures about $0.4 \mathrm{~mm}$ across, and reflects a retarded calcification that is documented by ornament of shrunken and wrinkled organic shell preserved by the aragonite layer formed below it (Fig. 3 D). The transition to the second whorl is characterized by the onset of a spiral keel, forming at short distance to the suture, and several delicate spiral striae composed of minute periostracal bristles (Fig. $3 \mathrm{C}$ ). This keel later develops into a prominent sutural carina (Fig. $3 \mathrm{~B}$ ). After hatching the prominence of the spiral ornamentation is quite variable and the carina usually becomes less prominent. The hatchlings of Bellamya sp. have a maximum shell height of about $6 \mathrm{~mm}$ (Fig. $3 \mathrm{~B}$ ) and regarding their organization and behaviour closely resemble that of the adults with which they were found to be associated.

Brotia aff. costula revealed to have a brood pouch in the head-foot, which contained numerous small eggs but no shelled embryos. Even though the early ontogeny could not be observed directly, the protoconch displays its course. It can be assumed to be similar to those of lecithotrophic thiarids (see below ; Riedel 1993, Bandel \& Kowalke 1997). The initial shell is shrunken and wrinkled, reflecting the typical characters due to retarded calcification. Hatching into the brood pouch presumedly took place with a shell size of $2 / 3$ whorls (Fig. $3 \mathrm{~K}$ arrow), measuring about $0.17 \mathrm{~mm}$ across. The maximum diameter of the first whorl is $0.24 \mathrm{~mm}$. The transition from a retarded to a simultaneous calcification is demarcated after completion of one and a half shell whorls and succeeded by the onset of spiral and axial ornamentation that is quite variable. Spiral and axial sculpture form a reticulated pattern on the upper flanks of whorls 3 to 5 (Fig. $3 \mathrm{~J}$ ). Afterwards the axial ribs predominate the ornament, which is also the case in the adult shell (Fig. $3 \mathrm{I}$ ). It remains unknown at what stage of growth the juvenile leaves the maternal brood pouch but in comparison with thiarids of similar developmental type it may have happen with a shell size of 4 to 5 whorls (see remarks).

Specimens of Tarebia cf. granifera were dissected and embryos of different developmental stages could be extracted from the brood pouch in the head-foot. Stages included as well embryos forming an initial shell cap as such bearing a shell of more than six whorls and ready to leave the brood pouch (and all intermediate stages). Each egg is surrounded by a spherical capsule. When the embryo hatches from the anterior oviduct into the posterior compartments of the brood pouch it has formed only three quarters of a loosely calcified whorl measuring about 0.19 to $0.23 \mathrm{~mm}$ across (Fig. 4 B). Subsequently the embryo develops through a short larval phase, showing two small velar lobes, one on each side of the head respectively. Metamorphosis occurs already when the first whorl of the shell is completed, which has a diameter of 0.25 to $0.29 \mathrm{~mm}$. The early juveniles feed on foamy particles of tissue delaminating from the brood pouch walls.

A-two-whorled juvenile already resembles a minüte adult, but, while migrating to the anterior portion of the brood pouch, develops a five- to six-whorled shell before it finally leaves the maternal shelter (Fig. $3 \mathrm{~N}$ ). A six-whorled shell is almost $5 \mathrm{~mm}$ high, which represents a fifth of the final height of the adult shell (Fig. 3 L). The sculptural development of Tarebia is characterized by the more or less irregularly shaped and wrinkled initial whorl and the subsequent onset of distinct growth increments and spiral lirae. From growth increments axial ribs develop, which become more or less nodular in the adult, and the lirae correspondingly increase in strength. The ornamentation of adult Tarebia varied comparatively little in the Matutinao population. The juveniles of $T$. cf. granifera were found in association with the adults.

Species of Gyraulus and Radix spawn jelly egg masses and attach them to hard substrate. The development of embryos of $G$. cf. chinensis and $R$. cf. quadrasi was not observed but from comparison with congeneric species reared in aquarium tanks it can be assumed that the embryos develop 8 to 9 days until they hatch (compare Bandel 1982, Riedel 1993). The protoconchs of the two Matutinao species could be exami- 


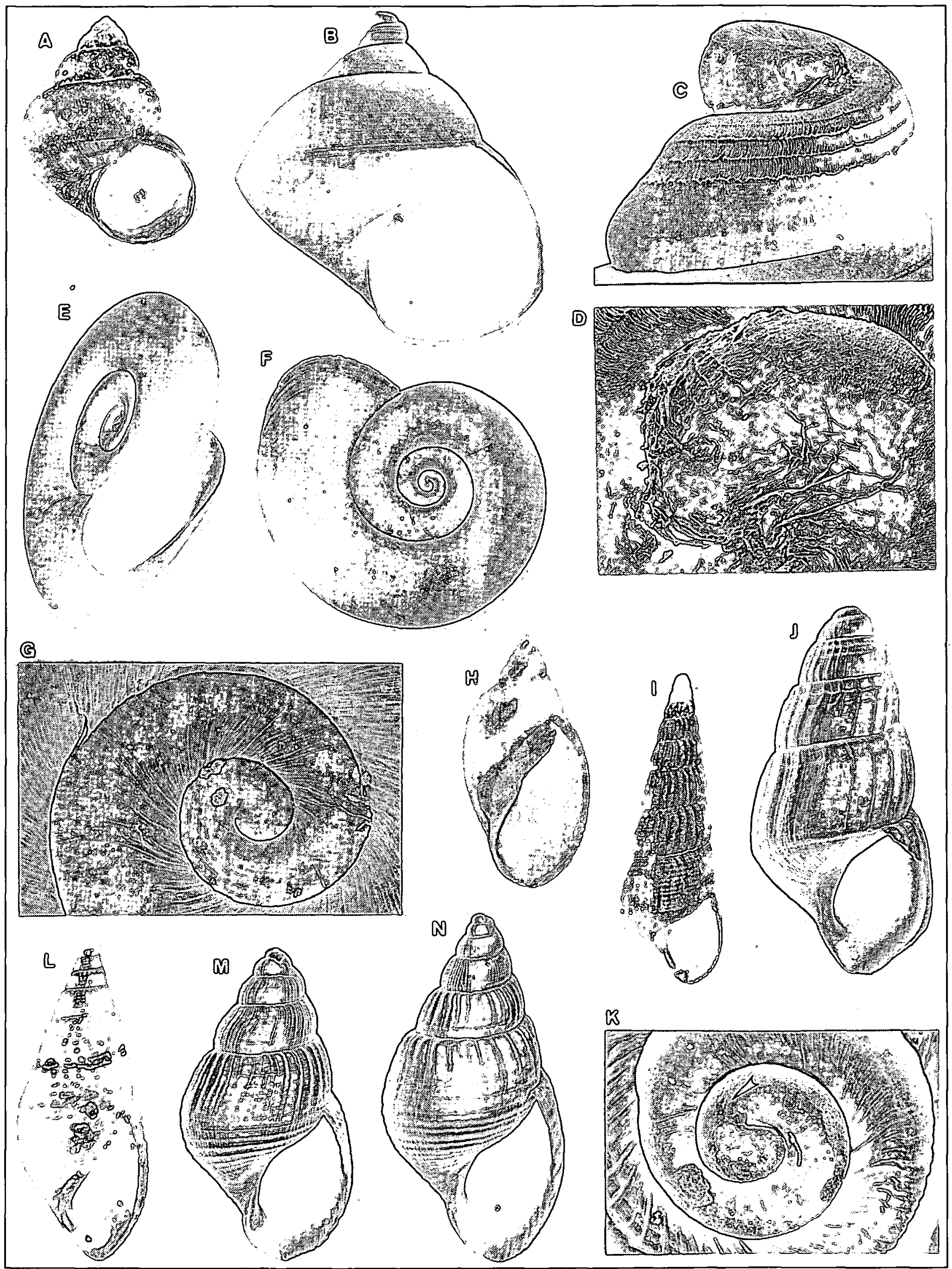

Fig.3. Gastropods from river sections 1,2 and 3. - A : Shell of adult Bellamya sp. Max. height $=3.0 \mathrm{~cm}$. B : Shell of largest embryonic stage of $B$. sp. removed from oviduct. Max. height $=6.0 \mathrm{~mm}$. C : Apex of $B$. sp. Max. width of photograph $=0.95 \mathrm{~mm}$. D : Close-up of initial whorl of $B$. sp. Width of photograph $=0.4 \mathrm{~mm}$. E : Shell of adult Gyraulus cf. chinensis in apertural view. Max. width $=4.3 \mathrm{~mm}$. F $:$ Shell of adult $G$. cf. chinensis in umbilical view. Max. width $=4.3 \mathrm{~mm}$. G : Apical close-up of initial whorl of $G$. cf. chinensis. Width of photograph $=0.75 \mathrm{~mm}$. $\mathrm{H}$ : Teleoconch of Radix cf. quadrasi. Max. height $=1.3 \mathrm{~cm}$. I : Shell of adult Brotia aff. costula. Max. height $=3.4 \mathrm{~cm}$. $\mathrm{J}:$ Shell of juvenile $B$. aff. costula. Max. height $=3.4 \mathrm{~mm} . \mathrm{K}:$ Close-up of initial whorls of $B$. aff. costula. Max. width of photograph $=0.55 \mathrm{~mm}$. L $:$ Shell of adult Tarebia cf. granifera. Max. height $=2.3 \mathrm{~cm} . \mathrm{M}$ : Shell of embryonic $T$. cf. granifera removed from brood pouch. Max. height $=3.5 \mathrm{~mm} . \mathrm{N}$ : Shell of embryonic $T$. cf. granifera removed from brood pouch. Max. height $=4.7 \mathrm{~mm}$. 
ned and exhibit features characteristic of the genera. $G$. cf. chinensis hatches with a 1.3-whorled shell measuring $0.35 \mathrm{~mm}$ across. Apart from growth increments this embryonic shell is sculptured by delicate but distinct lirae of which about eight can be counted in apical view of the planispiral conch (Fig. $3 \mathrm{G}$ ). The hatchling of $R$. cf. quadrasi is also shelled with 1.3 whorls, however, the diameter of these amounts to about $0.7 \mathrm{~mm}$ and the ornamentation is confined to faint axial growth lines.

Remarks : Brown (1980, p.16) figured a sketch of the early ontogenetic shell of Bellamya unicolor (OLIVIER, 1804) from northeastern Africa. It exhibits the same early introduction of a spiral carina, however, two additional carinae appear subsequently and the embryos are reported to hatch with a shell of about three whorls.

$T$. cf. granifera may represent a parthenogenetic species because no males were found. The latter was also true for $B$. aff. costula of which, however, functional males had previously been described (Davis 1971: $B$. costula episcopalis, compare Brandt 1974 and Dudgeon 1989). This may also imply that our species is a different one. Judging from teleoconch and gross anatomical features, however, differences could not be recognized. The radular teeth were examined and show the characteristical features of Pachychilinae, as sketched by Sarasin \& Sarasin (1898) and recently documented in detail for the closely related Potadoma SWAINSON, 1840 (see Samé-Ekobo \& Kristensen 1985). In contrast to the radula, the protoconch of Brotia aff. costula, resembles that of lecithotrophic Thiara. Davis (1971) dissected individuals of Brotia costula episcopalis and found shelled embryos with a maximum size of three and a half whorls, supporting our ontogenetic reconstruction.

\section{SPRING-LAKE-SECTION}

Associated gastropods : Bellamya sp. indet., Brotia aff. costula, Tarebia cf. granifera

Ecological characteristics : Brotia represented the dominant species in this section and the population was particularly dense where the spring issued from the limestone rocks and water flowed down rapidly into the artificial lake. Where the water current was slower $T a$ rebia joined Brotia and in the actual lake only some Bellamya and very few individuals of the two cerithioideans were present. The dam marked the lowermost occurrence of Bellamya (but compare section 4).

Life-cycles : see section 1

\section{KAWASAN FALLS}

Associated gastropods : Brotia aff. costula, Tarebia cf. granifera

Ecological characteristics : The gastropod distribution of the section from the dam to the large pools, which have been created by the main falls was obviously controlled by the high water energy. Brotia clearly dominated where water flowed rapidly, while Tarebia appeared in highest numbers in the smaller and larger pools with more moderate currents. The densest population of Tarebia within the whole river could be established for the large pools below the falls. Here the direct sunlight had triggered a significantly increased growth of water plants.

Life-cycles : see section 1

\section{Power-Station-Section}

\section{Associated gastropods :}

Superfamily Neritoidea RAFINESQUE, 1815

Family Neritidae RAFINESQUE, 1815

Subfamily Neritinae RAFINESQUE, 1815

Genus.Neritina LAMARCK, 1816 - with $N$. pulligera (LINNAEUS, 1758), $N$. sp. indet.

Genus Clithon MONTFORT, 1810 - with $C$. aff. corona (LINNAEUS, 1758)

Genus Septaria FÉRUSSAC, 1807 - with $S$. cf. porcellana (LINNAEUS, 1758), S. cumingiana RÉCLUZ, 1842

Superfamily Cerithioidea

Family Thiaridae

Subfamily Thiarinae

Genus Melanoides OLIVIER, 1804 with $M$. cf. tuberculata (MUELLER, 1774)

a n d Brotia aff. costula, Tarebia cf. granifera

Ecological characteristics : The upstream dominance of Brotia and Tarebia ended abruptly about 50 me-ters below the power station. Some Bellamya were introduced here via the pipeline but they were not thriving well and could not colonize this section. They only occurred where the water from the power station joins the river having washed them in from the lake. The neritimorphan gastropods Clithon, Neritina and Septaria appeared with five species in large numbers on and around the boulders which compose the substrate of the river for about 400 meters downstream. These boulders create a series of short waterfalls, cascades and pools and thus a diverse pattern of currents, which obviously represented the main controlling factor in respect of species zonation.

$S$. cf. porcellana (Fig. 4 L-M) preferably occupied the surfaces of the boulders and was exposed to the 


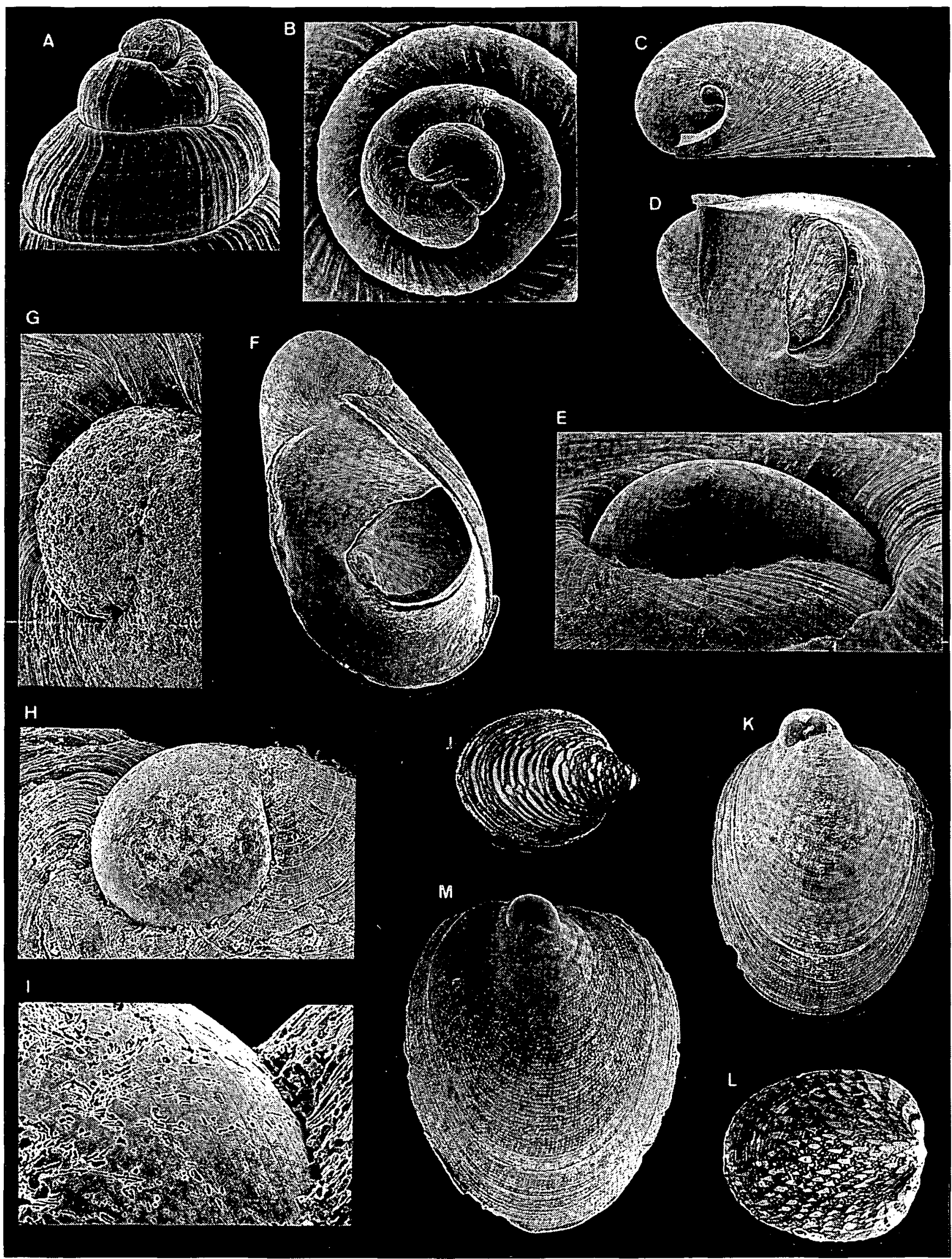

Fig.4. Gastropods from river sections 3 and 4. - A : Close-up of early ontogenetic whorls of Tarebia cf. granifera. Width of photograph $=0.8$ $\mathrm{mm}$. B : Early ontogenetic whorls of $T$. cf. granifera in apical view. Width of photograph $=0.5 \mathrm{~mm}$. C : Shell of juvenile Neritina pulligera in apical view. Max. width $=4.0 \mathrm{~mm}$. D : Shell of juvenile $N$. pulligera in apertural view. Max. width $=3.8 \mathrm{~mm}$. E : Close-up of protoconch of $N$. pulligera. Max. width of photograph $=0.56 \mathrm{~mm}$. F : Shell of juvenile Neritina sp. Max. width $=3.0 \mathrm{~mm}$. G : Close-up of encrusted protoconch of $N$. sp. Height of photograph $=0.62 \mathrm{~mm} . \mathrm{H}:$ Close-up of cleaned protoconch of $N$. sp. Width of photograph $=0.58 \mathrm{~mm}$. I : The larval shell of $N$. sp. shows characteristic axial ridges. Width of photograph $=0.17 \mathrm{~mm}$. J : Shell of adult Septaria cumingiana. Max. length $=2.0 \mathrm{~cm}$. $\mathrm{K}$ : Shell of juvenile $S$. cumingiana with protoconch. Max. length $=2.2 \mathrm{~mm}$. L : Shell of adult Septaria $\mathrm{cf}$. porcellana. Max. length $=2.3 \mathrm{~cm}$. $\mathrm{M}$ : Shell of juvenile $S$. cf. porcellana with protoconch. Max. length $=2.8 \mathrm{~mm}$. 
highest available water energy. S. cumingiana (Fig. 4 $\mathrm{J}-\mathrm{K}$ ) was mainly found on surfaces of such boulders where currents were comparatively more moderate but not slow. N. pulligera (Fig. $4 \mathrm{C}$-E) settled mainly on the lateral sides of rocks, within a micro-current-regime similar to that of $S$. cumingiana. Neritina sp. (Fig. 4 F-I) appeared in significantly lower numbers than the other species and was found in particular on larger shells of living Melanoides and less commonly on the surfaces of boulders found in the inner tracks of river curves. Clithon aff. corona (Fig. 5 A-K) was the dominating species within the pools. Of the latter four species single individuals were found in areas exposed to higher water energy as was characteristic of their preferred habitats. All these neritimorphan gastropods browsed on the rocky substrate and different specific feeding strategies were not apparent. S. cf. porcellana revealed homing behaviour.

The thiarid Melanoides cf. tuberculata (Fig. 5 L-M) was only moderately abundant in this section and mainly found near the river banks avoiding stronger currents. Individuals browsed on algal films that covered pebbles and boulders.

Life-cycles : The five neritoidean species produced more or less flattened hemi-ellipsoidal egg capsules which were attached to the rocky substrate and to shells of available gastropods. The capsules could be distinguished in the field only at generic level i.e. by the brownish colour in Septaria and the whitish colour in Neritina and Clithon. Of the latter two genera Clithon capsules have a smaller maximum diameter, which is about $1 \mathrm{~mm}$, and about $1.5 \mathrm{~mm}$ in Neritina pulligera (and Septaria). The capsules of the significantly less abundant Neritina sp. were not identified but are presumedly smaller than in Clithon.

Several hundred egg capsules were opened and each yielded about 200 to 300 embryos, which showed the typical morphology of larvae preparing for planktotrophic development in the sea (for details and comparison see Bandel 1982, Bandel et al. 1997b). The embryos from all three different egg capsules hatch with a shell diameter of about $0.15 \mathrm{~mm}$, a functional operculum and a bilobed velum propelling the larva through the water. There are no obvious differences between species. To reach the estuary and finally the open sea, the larvae have to survive a maximum distance in freshwater of $1 \mathrm{~km}$ or $1.5 \mathrm{~km}$ inclusive the brackish section. This means that a fairly high number of larvae may reach the sea in less than half an hour, some even in ten minutes, while others are delayed by whorling water in pools or by lateral countercurrents. Freshly hatched veligers were kept in glass vessels and stayed alive for almost two days, during which they usually have already reached the marine environment, showing that the larvae are quite tolerant in respect of salt content.

The veligers remain in the marine plankton at least for several weeks (Bandel 1982) and develop during this phase a more or less globular, mulitispiral and characteristically convolute larval shell (see e.g. Fig. 5 $E, G, J)$. The protoconch (embryonic and larval shell) of the five neritoidean species show identical features. All protoconchs measure about 0.4 to $0.45 \mathrm{~mm}$ across (with dissolved columella, which is characteristic of all neritoideans). The larval whorls show spiral striae, distinct growth lines and about 30 opisthocline, axial ridges on the final half whorl (Fig. 4 E, Fig. 5 F,J). Those veligers, which are ready to metamorphose and lucky enough to reach the estuary of a river, settle on the available hard substrate.

In the estuary of the Matutinao River innumerable specimens of recently settled neritoideans could be observed. The initial postmetamorphic shell growth was apparently very fast as no specimens could be found not having secreted a distinct early juvenile shell (Fig. $5 \mathrm{G})$. The spiral angle of the first teleoconch whorl clearly indicates to which of the three possible genera an individual can be assigned. The increasing size of the juvenile neritoideans generates an increasing speed of possible upstream migration. Part of the Clithon aff. corona settlers and Neritina sp. remained and obviously grew up in the upper estuary, while the two Septaria species (but not a third one, see below) as well as Neritina pulligera preferred to enter the zone that lies totally outside marine influence. The upstream migrants of Septaria, Neritina pulligera and Clithon were more or less full-grown at a distance of only a few hundred meters from the upper estuary. Vice versa : no early juveniles were found outside of the estuarine area and late juveniles only rarely. Further upstream not a single juvenile of the three neritoidean genera could be detected and thus it was very surprising that in the upper reaches of section 4 , within the ecologically transitional portion directly below the power station, suddenly also some juveniles of Septaria, Clithon and Neritina sp. appeared (see discussion).

Melanoides $\mathrm{cf}$. tuberculata revealed a brood pouch in the head-foot which contained shelled juveniles. The largest specimen was five-whorled and probably ready to leave the pouch. The initial 1.5 -whorls with their characteristic wrinkles, and reticulated ornamentation of subsequent whorls respectively (Fig. $5 \mathrm{M}$ ), resemble those of lecithotrophic Thiara $\mathrm{cf}$. cancellata (see below). Hatching into the brood pouch presumed- 


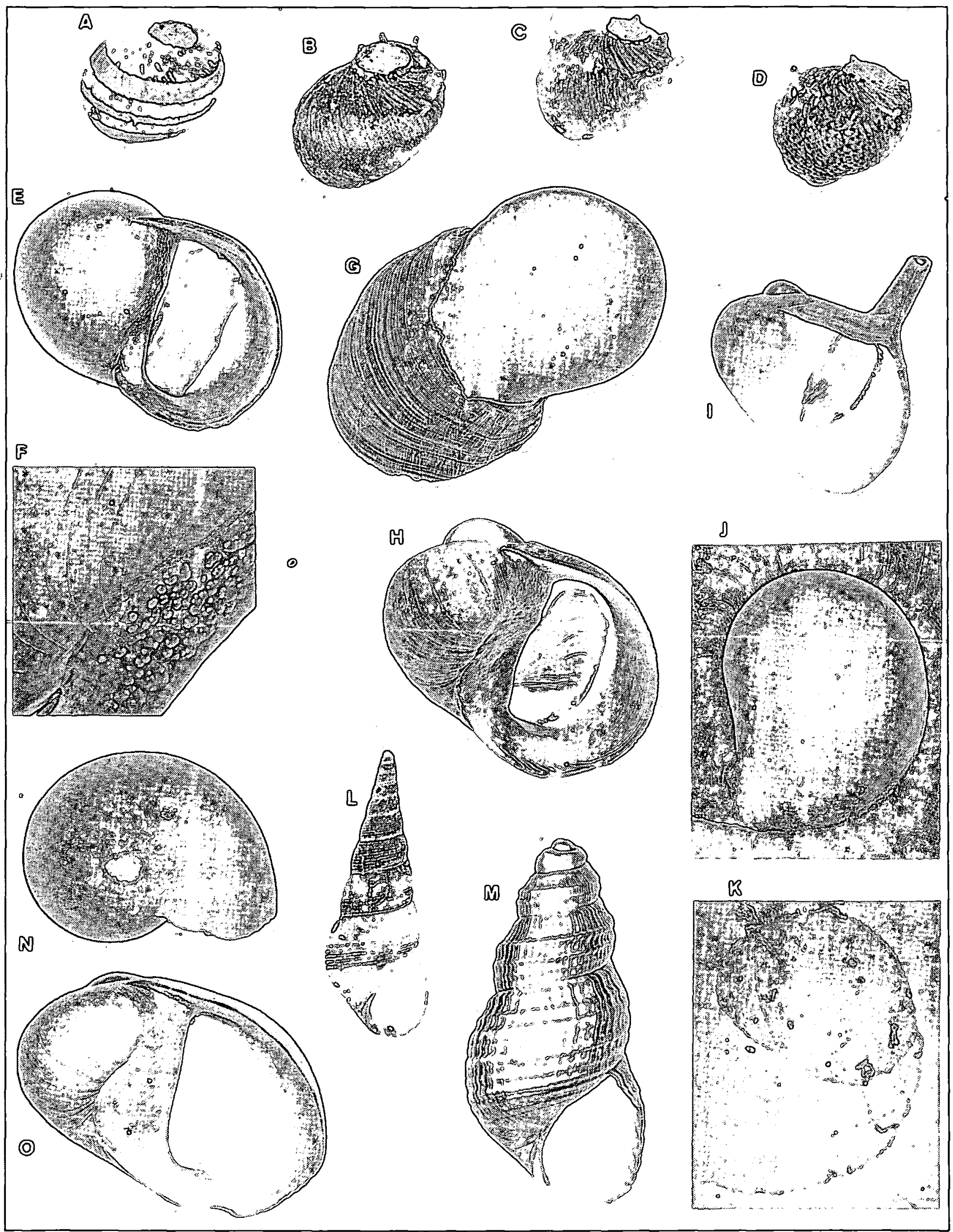

Fig. 5. Gastropods from river section 4 and 5. - A-D : The adult shells of Clithon aff. corona show significant intraspecific variation of the colour pattern. Max. diameter of specimen $A=1.3 \mathrm{~cm}$. $\mathrm{E}:$ Early juvenile shell of $C$. aff. corona in apertural view. Max. diameter $=0.55 \mathrm{~mm}$. $\mathrm{F}:$ Detail of E showing characteristic axial ridges of the larval shell and granules on the columellar lip. Width of photograph $=0.1 \mathrm{~mm}$. G : In $C$. aff. corona the transition from larval to juvenile shell is clearly demarcated. Max. diameter $=0.58 \mathrm{~mm}$. $\mathrm{H}:$ Juvenile shell of $C$. aff. corona in apertural view. Max. diameter $=1.25 \mathrm{~mm}$. I : Juvenile shell of $C$. aff. corona with formation of the first spine. Max. diameter $=2.0 \mathrm{~mm}$. J : Protoconch of $C$. aff. corona in apical view. Width of photograph $=0.37 \mathrm{~mm}$. K : Detail of J showing embryonic shell which is mostly hidden by subsequent convoluted larval whorls. Width of photograph $=0.11 \mathrm{~mm} . \mathrm{L}:$ Shell of adult Melanoides $\mathrm{cf}$. tuberculata. Max. height $=3.1 \mathrm{~cm}$. M : Shell of embryonic $M$. cf. tuberculata removed from brood pouch. Max. height $=2.6 \mathrm{~mm}$. N : Shell of juvenile Neritilia cf. rubida in apical view. Max. diameter $=1.8 \mathrm{~mm}$. O : Shell of juvenile $N$. cf. rubida in apertural view. Max. diameter $=1.35 \mathrm{~mm}$. 
ly takes place within a 0.7 -whorled embryo measuring $0.18 \mathrm{~mm}$ across. The complete first whorl has a maximum diameter of $0.21 \mathrm{~mm}$ (see remarks).

Remarks : The assignment of Septaria cumingiana and $S$. cf. porcellana has been suggested by the unknown referee who presented himself as taxonomic authority. In the original manuscript we called the former species $S$. cf. porcellana and the latter $S$. cf. borbonica.

The shell colour pattern of Clithon aff. corona is here less variable than in the estuarine section, where spines are commonly formed, while they are mostly absent in the specimens of this section. This appears to indicate that two different species occur in the Matutinao River, however, the shell characters of the more upstream individuals are fully within the morphological range of corresponding features of the estuarine specimens. In respect of spines it may be true that fish represents the selective pressure. In contrast to the estuary there are no fish species in section 4 , which may prey on Clithon.

Neritina sp. like the other neritoideans described here could be detected in the estuarine transition (see below), which appears logical in the context of the early ontogeny. However, in contrast to these, populations of $N$. sp. seemed to be separated by a distributional gap of almost 500 meters in which not a single specimen could be found (see discussion).

The apex of Neritina sp. was conspicuously crusted over with calcium carbonate even in early juveniles (Fig. $4 \mathrm{G}$ ). This crust has been formed by the activity of cyanobacteria, which probably preferred or were most successful on the species exposed to the relatively lowest water energy.

The life-span of our fluvial neritoideans is very difficult to be calculated. A Neritina from Bali (Indonesia), which was already adult when collected, has been kept alive in an aquarium tank (at the University of Hamburg) for more than seven years. This may provide a rough idea and indicate that Neritina and relation can reach a rather great age and thus migrate far up a river, even with very little daily progress (compare Schneider \& Frost 1986 and see discussion).

The shell of Melanoides cf. tuberculata cannot be differentiated from $M$. tuberculata collected in Jordan (see Riedel 1993), perhaps except for the larger initial whorl found in the Matutinao River species. This feature, however, has not yet been checked with regard to its ecological context. A very similar juvenile shell can also be found in Stenomelania plicaria (see Bandel et al. 1997a, and below), where it is, however, significantly slenderer (Fig. 6 I).

\section{ESTUARINE TRANSITION}

\section{Associated gastropods :}

Superfamily Neritoidea

Family Neritidae

Subfamily Neritiliinae BAKER, 1923

Genus Neritilia MARTENS, 1879 - with $N$. cf. rubida (PEASE, 1865)

Superfamily Cerithioidea

Family Thiaridae

Subfamily Thiarinae

Genus Thiara RöDING, 1798 - with T. cf. scabra (MÜLLER, 1774), T. cf. cancellata (ROEDING, 1798)

Genus Stenomelania FISCHER, 1885 - with S. punctata (LAMARCK, 1822), S. plicaria (BORN, 1780)

a n d Clithon aff. corona, Neritina pulligera, N. sp, Septaria cf. porcellana, S. cumingiana, Melanoides $\mathrm{cf}$. tuberculata

Ecological characteristics : Neritilia (Fig. $5 \mathrm{~N}-\mathrm{O}$, Fig. $6 \mathrm{~A}-\mathrm{B}$ ) was found attached to available hard substrates, most commonly to the undersides of rocks and to shells of syntopic larger gastropod species such as Stenomelania spp. Neritilia occurred also on sunken branches of terrestrial plants and only rarely on pebbles and larger stones, usually in places with low water energy. Stenomelania moved on sandy and muddy substrates, in particular in quiet places right below the river banks. The two species $S$. plicaria (Fig. $6 \mathrm{I}-\mathrm{K}$ ) and S. punctata (Fig. $6 \mathrm{~L}-\mathrm{N}$ ) revealed the same habitat preference (compare Bandel et al. 1997a). The low number of quiet, soft substrate habitats corresponded with the comparatively small populations.

A single adult and several juvenile specimens of Thiara cf. cancellata (Fig. 6 F-H) were found burried in sand deposited at the northeasterly flank of the narrow island, which terminates at the actual estuary. Thiara cf. scabra (Fig. 6 C-E) occurred in fair numbers in sandy places along the island and the opposite bank. Most specimens were burried in sand, only very few crawled on the substrate. The alimentary tract of dissected animals exhibited fine sand and thus Thiara obviously fed on organic particles.

The other species met in this section have already been characterized in connection with preceding river sections.

Life-cycles : Aside from Stenomelania plicaria, Melanoides $\mathrm{cf}$. tuberculata and Thiara $\mathrm{cf}$. cancellata, all 
species of this section release free-swimming veligers, which feed on marine plankton (for Clithon, Neritina and Septaria see section 4). The egg capsules of Neritilia cf. rubida were not identified in the field, but have the same general shape as found in Neritina. Ontogenetic stages are reflected by shell features and the ecological zonation. $N$. cf. rubida produces eggs, which develop to veligers with a shell diameter of about 0.11 $\mathrm{mm}$ when hatching. The veligers have to cope with freshwater for only a short distance until they reach the estuary or hatch at the estuary proper respectively. Considering the biogeography of $N$. cf. rubida it must be concluded that the larvae remain and feed in the marine plankton for at least several weeks. The veligers develop a multispiral globular shell which measures $0.27-0.29 \mathrm{~mm}$ across when the larva is ready to metamorphose (Fig. $6 \mathrm{~A}$ ). Spiral rows of pits produce a characteristical ornament (Fig. 6 A-B). Metamorphosis occurred preferably in the upper reaches of the estuary from where most individuals migrate into the freshwater and only few remain in the brackish influence. Migration is sometimes supported by larger gastropods which may be used as carriers by the minute Neritilia.

Thiara cf. scabra was dissected and the brood pouch in the head-food revealed hundreds of developing eggs with a maximum diameter of $0.2 \mathrm{~mm}$. The apeces of juveniles (Fig. $6 \mathrm{D}$ ) exhibit a protoconch which is characteristic of larval planktotrophic development. A more or less smooth embryonic part of 0.8 whorls measuring $0.16 \mathrm{~mm}$ across can be differentiated from about one larval whorl, which is ornamented by 7-9 spiral lirae and shows a typical sinusigera aperture (Fig.6E). The maximum width of the protoconch reaches $0.22 \mathrm{~mm}$ (height : $0.24 \mathrm{~mm}$ ). It thus can be concluded that the hatchlings leave the brood pouch, reach the marine environment via the river within a few minutes and feed on marine phytoplankton until they are ready to metamorphose and find the right conditions to settle. We observed that fully grown animals were not active under marine influence but only in freshwater. Thus it must be presumed that only larvae drifting within the upper reaches of the high tides have a good chance to settle successfully. They metamorphose during low tide when freshwater influence predominates, and then migrate upstream.

In contrast to $T$. cf. scabra the development of $T$. cf. cancellata is lecithotrophic. The only adult specimen found contained no shelled embryos in its brood pouch. The associated juveniles (Fig. $6 \mathrm{G}$ ), however, show the characteristical initial whorls of hatchlings having developed within a maternal brood pouch. The first 1.5 whorls show wrinkles and a more or less irregular shape
(Fig. $6 \mathrm{H}$ ). The embryos hatch with a 0.8 -whorled shell measuring almost $0.19 \mathrm{~mm}$ across. The complete first whorl has a maximum diameter of $0.24 \mathrm{~mm}$. Prominent ornamentation sets in at the transition to the second whorl where axial ribs develop, which are more or less immediately crossed by two or three spiral keels (intraspecific variation). Thus a reticulated pattern is formed, which remains a distinct shell feature (see name of the species) except for whorls five and six where the axial ribs are predominant (Fig. $6 \mathrm{G}$ ). The smallest juveniles found in the river secreted five and a half whorls, and, judging from comparison with Tarebia or Melanoides (see above), presumedly had left the brood pouch with a shell consisting of about five whorls. This coincides with the close spatial association of the adult specimen and juveniles, which probably represent parent and offspring.

Another species pair exhibiting different early ontogenies was found in Stenomelania (compare Bandel et al. 1997a). The dissection of $S$. punctata revealed several hundred eggs each with a diameter of about $0.2 \mathrm{~mm}$. This evidence clearly indicates a planktotrophic larval phase, which is directly supported by the features of the early ontogenetic shell (Fig. $6 \mathrm{~L}$ ). The protoconch can be differentiated in a more or less smooth 0.9-whorled embryonic shell measuring 0.15 $\mathrm{mm}$ across, and about 1.0-1.2 larval whorls (intraspecific variation) exhibiting a sinusigera aperture, and which are sculptured by 7-9 spiral lirae. The protoconch has a maximum width of $0.23 \mathrm{~mm}$ and is about $0.28 \mathrm{~mm}$ high. Thus the life-cycle corresponds with that of Thiara cf. scabra (see description there).

Stenomelania plicaria reveals the ontogenetic strategy of Melanoides (compare Brotia, Tarebia and Thiara cf. cancellata). This is in particular reflected by the very similar early ontogenetic shell (compare Fig. $5 \mathrm{M}$ with Fig. 6 I); which, however, is slenderer in S. plicaria (see remarks).

Remarks : Neritilia and Neritina are attributed by some authors to the same family Neritidae while Septaria represents the genotype of the Septariidae (e.g. Vaught 1989). The results here, however, show the close relation between Neritina and Septaria and there is no reason to separate the two genera at the family level. Moreover, it is Neritilia which may constitute a group apart from the other Neritidae. It must be considered that there are very few really different protoconch types within the Neritoidea and as was demonstrated here (see section 4) the corresponding shell features are not suitable for low level taxonomy. The protoconch of Neritilia cf. rubida is quite different from 


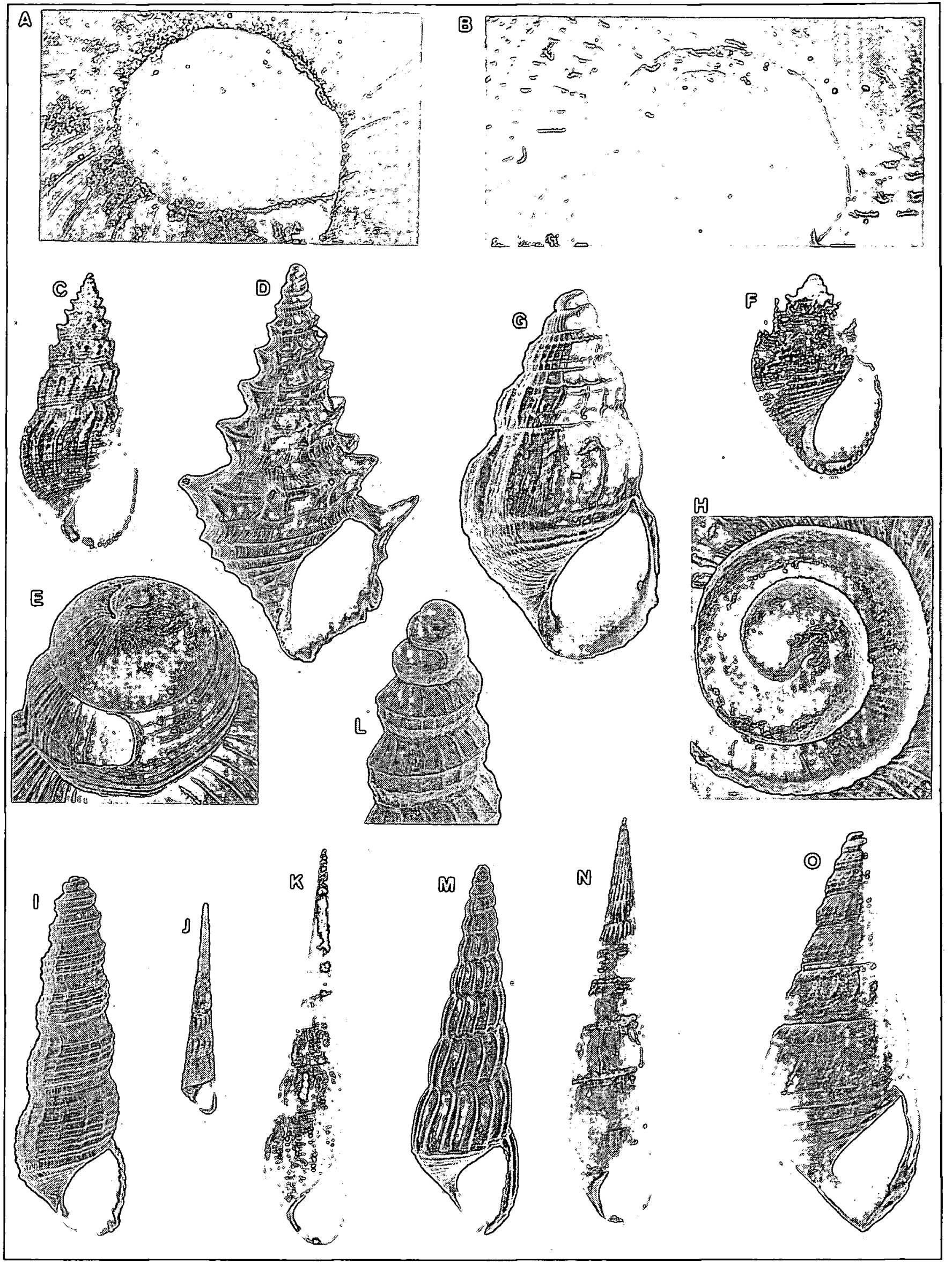

Fig. 6. Gastropods from river section 5 and 6. - A : Protoconch of Neritilia cf. rubida. Width of photograph $=0.48 \mathrm{~mm}$. B : Detail of A showing the convolute character of larval whorls and sculptural features. Width of photograph $=0.16 \mathrm{~mm}$. C : Shell of adult Thiara cf. scabra. Max. height $=3.3 \mathrm{~cm}$. D : Shell of juvenile $T$. cf. scabra. Max. height $=4.6 \mathrm{~mm}$. E : Protoconch of $T$. cf. scabra with larval sinusigera beak. Width of photograph $=0.27 \mathrm{~mm}$. F $:$ Shell of adult Thiara cf. cancellata. Max. height $=3.3 \mathrm{~cm} . \mathrm{G}:$ Shell of juvenile $T$. cf. cancellata. Max. height $=$ $3.0 \mathrm{~mm}$. H : Apical detail of G. Width of photograph $=0.36 \mathrm{~mm}$. I : Shell of juvenile Stenomelania plicaria. Max. height $=4.7 \mathrm{~mm}$. J : Shell of late juvenile $S$. plicaria. Max. height $=1.6 \mathrm{~cm} . \mathrm{K}:$ Shell of adult $S$. plicaria . Max. height $=4.4 \mathrm{~cm}$. L : Apex of juvenile Stenomelania punctata with sinusigera protoconch. Max. height $=0.78 \mathrm{~mm}$. M : Shell of juvenile $S$. punctata. Max. height $=5.5 \mathrm{~mm}$. N :Shell of adult $S$. punctata . Max. height $=4.6 \mathrm{~cm} . \mathrm{O}:$ Shell of juvenile Sermyla cf. riqueti. Max. height $=6.3 \mathrm{~mm}$. 
those of other neritoidean taxa. The characters appear to be consistent within the genus as exactly the same protoconch was found in a species from Columbia (Caribbean coast).

In respect of Thiara scabra, Glaubrecht (1996) figured specimens from Bali with a protoconch type reflecting lecithotrophic development. We do not have to discuss here a possible case of poecilogony because Glaubrecht (1996) misidentified the shells and actually figured juveniles of the thiarid Sermyla (compare below).

The two species of Stenomelania described here were recently investigated in more detail by Bandel et al. (1997a) from a different locality on the opposite side of Cebu Island, with regard to ontogeny, anatomy and ecology.

\section{ESTUARY}

Associated gastropods :

Superfamily Neritoidea

Family Neritidae

Subfamily Neritinae

Genus Clithon MONTFORT, 1810 - with C. oualaniensis (LESSON, 1831)

Genus Neritina LAMARCK, 1816 - with Neritina aff. auriculata (LAMARCK, 1816)

Genus Septaria FÉRUSSAC, 1807 - with Septaria cf. tesselata (LAMARCK, 1816)

Superfamily Littorinoidea GRAY, 1840

Family Littorinidae GRAY, 1840

Subfamily Littorininae GRAY, 1840

Genus Littorina FÉRUSSAC, 1822 - with L. scabra (LINNAEUS, 1758)

Superfamily Cerithioidea

Family Thiaridae

Subfamily Thiarinae

Genus Sermyla H. \& A. ADAMS, 1854 - with $S$. cf. riqueti (GRATELOUP, 1840)

Superfamily Ellobioidea H. \& A. ADAMS, 1855

Family Ellobiidae H. \& A. ADAMS, 1855

Subfamily Ellobiinae H. \& A. ADAMS, 1855

Genus Auriculastra MARTENS, 1880 - with A. subula (QUOY \& GAIMARD, 1832)

Subfamily Pythiinae OHDNER, 1925

Genus Pythia RöDING, 1798 - with $P$. reeveana PFEIFFER, 1853

Genus Cassidula FÉRUSSAC, 1821 - with C. vespertilionis (LESSON, 1831)

Subfamily Melampinae STIMPSON 1851
Genus Melampus MONTFORT, 1810 - with $M$. cf. fasciatus (DESHAYES, 1830)

Genus Micromelampus MÖLLENDORFF, 1898 - with $M$. aff. nucleolus (MARTENS, 1865)

a n d Clithon aff. corona, Neritilia cf. rubida

Ecological characteristics : Ten of the extant species occurred exclusively in this section, which means they were not found further upstream. Septaria cf. tesselata (Fig. 7 I-J, see remarks) was fairly commonly found attached to the water-covered parts of tree roots along the easterly banks of the river where the water energy was comparatively low, but also on pebbles, which were exposed to stronger water currents. Clithon oualaniensis (Fig. 7 L-M) was the dominant gastropod species of the actual river mouth whereas in the upper estuary $C$. aff. corona was most abundant (which continued up to section 4). C. oualaniensis occurred on pebbles, coarse gravel and sand, individuals browsing available organic matter. The single specimen of Neritina aff. auriculata (Fig. $7 \mathrm{~K}$ ) encountered was attached to the underside of a larger pebble, right below the westerly bank.

Littorina scabra (Fig. 7 E-H) was frequently found living on Nipa palms or sonneratiaceaen mangroves (Fig. 7 E), often exposed to sunlight. Individuals used their radula to scrape food from the leaves.

Sermyla cf. riqueti (Fig. 6 0, Fig. 7 A-D) preferred the muddy calm places in the uppermost estuary and here consumed diatoms and other microorganisms.

The extant archaeopulmonate species exhibited an amphibious habit, which is characteristic of ellobiids. Auriculastra subula (Fig. 8 A-C) was the most common archaeopulmonate and inhabited muddy ground, which was more or less covered by plant remains, and beyond the reach of the high tide. Pythia reeveana (Fig. $8 \mathrm{I}-\mathrm{K}$ ) preferred to hide under rotting plant material in the uppermost tidal reaches i.e. at the transition from Nipa to Cocos palms. Cassidula vespertilionis (Fig. $8 \mathrm{~L}$ ) lived on soft substrate within the reach of the high tide but stopped activities when being flooded. Micromelampus aff. nucleolus (Fig. $8 \mathrm{D}-\mathrm{H}$ ) was almost as common as $A$. subula and occurred on the substrate among the petioles of the Nipa palms and the roots of the sonneratiaceaen mangrove trees, i.e. mud flats within the reach of the tide. Melampus aff. fasciatus (Fig. $8 \mathrm{M}$ ), the largest of the extant ellobiids, was usually found sympatric with $P$. reeveana, but also hidden in crustacean burrows.

Life-cycles : Egg capsule and protoconch (Fig. $7 \mathrm{~J}$ ) of Septaria cf. tesselata appear to be identical with those of $S$. cf. porcellana and $S$. cumingiana (for des- 
cription see section 4 ). The embryos hatch out as bilobed veligers, are carried by the main river current or by the receding tide to the sea and feed on the marine nannoplankton for at least several weeks before metamorphosing and settling within a convenient estuary. The early ontogenetic shell of Neritina aff. auriculata was corroded in the single available specimen and thus information about the premetamorphic feeding strategy could not be attained. It is assumed, however, that there is a planktotrophic larval phase (see remarks). Clithon oualaniensis shows the same protoconch type as was described here for all neritids except for Neritilia cf. rubida, but can be distinguished in detail by its larger maximum diameter of $0.53 \mathrm{~mm}$. Thus there is no doubt that $C$. oualaniensis has a planktotrophic phase in its early ontogeny (see remarks).

Littorina scabra exhibits a life cycle, which is typical for many members of the family. Although individuals may usually live several meters above the water surface, the egg capsules have to be deposited within the tidal reach. Thus females have to come down to the water to be able to spawn. The planktic egg capsules are carried by the tide to the open sea. The embryos hatch out as bilobed, one-whorled veligers. It is assumed that the larvae remain in and feed on plankton for several weeks during which almost three whorls are added to form a four-whorled protoconch (Fig. $7 \mathrm{H}$ ). The larval whorls are sculptured by 4-6 spiral ridges. The protoconch has a height of $0.42-0.44 \mathrm{~mm}$ and a maximum width of about $0.27 \mathrm{~mm}$.

Sermyla cf. riqueti. shows the reproductive biology, which is characteristic of all thiarids. Dissection of animals revealed a brood pouch in the head-foot of females, which contained different stages of about twenty shelled juveniles (Fig. 7 A-B), sometimes having a pathologic sinistral shell (Fig. 7 D). The embryos hatch into the brood pouch with a shell of three quarters of a whorl, measuring $0.16 \mathrm{~mm}$ across. Up to 1.5 whorls the shell shows more or less prominent wrinkles, which reflect a retarded calcification (Fig. $7 \mathrm{C}$, see above). After that growth lines become distinct and 2-3 spiral keels are introduced (Fig. 7 B). On the third whorl axial ribs develop, which become increasingly opisthocline on later whorls and represent a characteristic feature of the teleoconch (Fig. $6 \mathrm{O}$ ). The largest juveniles found within brood pouches had formed 4.5 whorls with a height of $1.4 \mathrm{~mm}$ and a maximum width of about $0.82 \mathrm{~mm}$ (Fig. $7 \mathrm{~B}$ ). These were probably ready to leave the maternal pouch and join the population.

The shells of the six archaeopulmonates, as could be expected, exhibit a change of the coiling direction from sinistral (protoconch) to dextral (teleoconch).
The spawn of Auriculastra subula consists of oval capsules, each containing a single egg, and which are embedded in mucus to form a gelatinous flattened eggmass. The embryos develop to planktotrophic veligers within seven days (see remarks). Hatching appears to be controlled by the lunar cycle and takes place particularly during spring tides. The newly hatched veliger has no tentacles, no eyes and no mantle cavity. The shell is fully mineralized and can be sealed by an operculum. The more or less smooth protoconch is distinctly sinistral (Fig. 8 B-C), measures about $0.2 \mathrm{~mm}$ across, and indicates that the larva remains in the plankton up to several weeks before it metamorphoses and the juvenile commences its amphibious life-style.

It is assumed that Pythia reeveana spawns similar egg masses and has a comparable ontogeny as the larger species $P$. scarabaeus (LINNÉ, 1758) from Bali, which could be examined in more detail (see remarks). The one-whorled protoconch of $P$. reeveana measures $0.3 \mathrm{~mm}$ across and is indistinctly sinistral (Fig. $8 \mathrm{~K}$ ). It can be considered to reflect the ontogenetic phase of a short-lived veliger, which probably metamorphoses right after to several days after hatching.

The protoconch of Cassidula vespertilionis cannot be documented and the potential to distribute remains unclear (compare Harbeck 1997). Micromelampus aff. nucleolus reveals the same protoconch type (Fig. 8 G$\mathrm{H}$ ) as can be found in Melampus aff. fasciatus (see Harbeck 1997). In apical view the protoconch is eggshaped (Fig. $8 \mathrm{H}$ ), revealing the final half whorl of a sinistral, involute shell, which is largely hidden within the initial teleoconch whorl. The visible portion of the protoconch measures $0.22 \mathrm{~mm}$ at its maximum diameter. The embryos hatch out as bilobed, planktotrophic veligers (see remarks), which have the potential to remain in the plankton for several weeks. As in the other extant archaeopulmonates, life after metamorphosis proceeds only if a suitable environment is reached and amphibious life-style can be established.

Remarks : In respect of Clithon oualaniensis we put emphasis on the fact that the species has a planktotrophic larval phase because in the literature authors discussed lecithotrophy. Gardner et al. (1995) wrote that «... it is unlikely that Clithon has a free-swimming pelagic larva (Gruneberg 1976), ...», which is obviously wrong.

Auriculastra subula, Pythia scarabaeus, Melampus fasciatus and Micromelampus pulchellus (PETIT, 1842) were collected by Klaus Bandel and Klaus Harbeck in Bali and taken alive to their institute in Hamburg. The ellobiids were kept in aquarium tanks and spawned egg masses. The data for $A$. subula and $M$. 


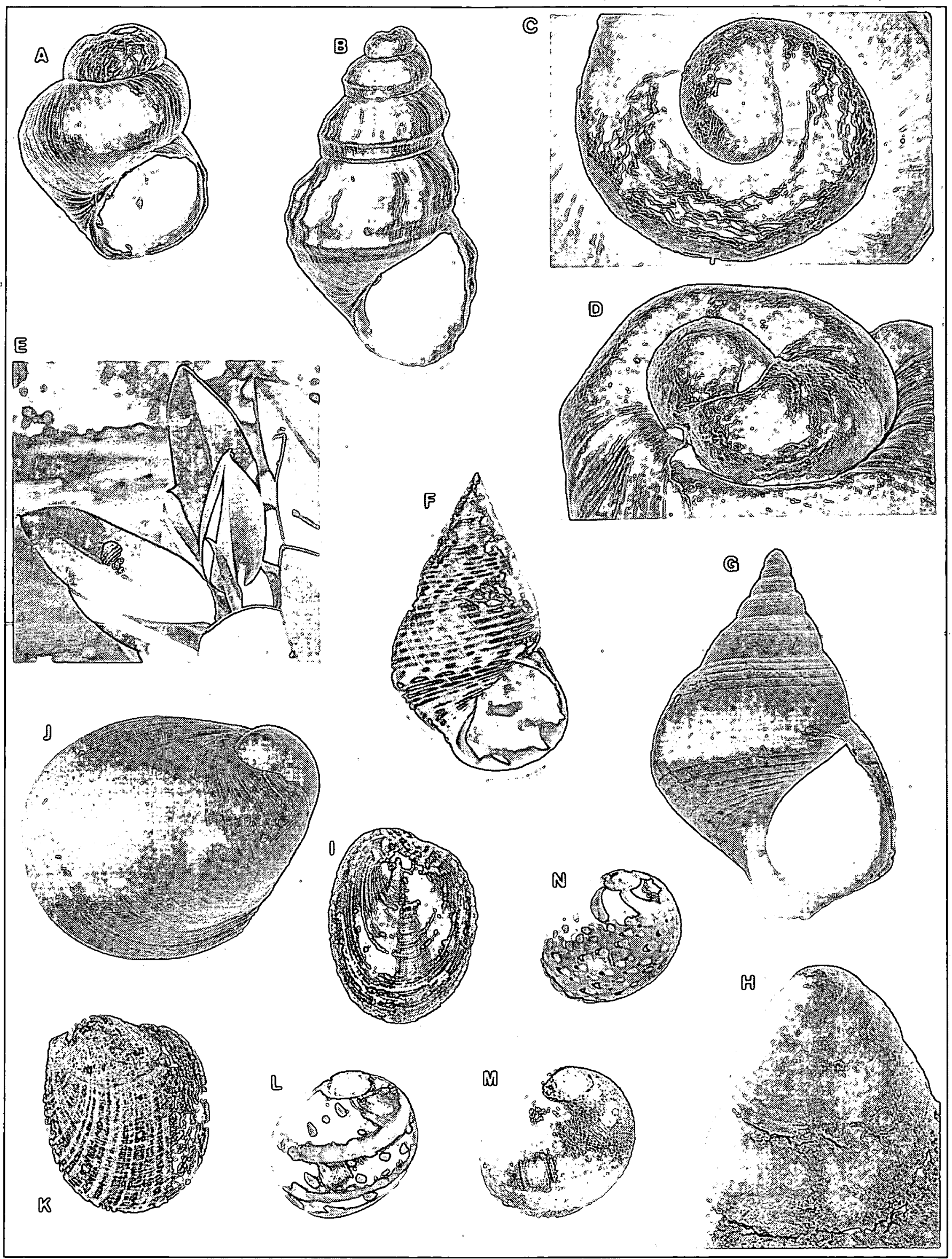

Fig. 7. Gastropods from river section 6. - A : Shell of early embryogenetic stage of Sermyla cf. riqueti removed from brood pouch. Max. height $=0.56 \mathrm{~mm}$. B : Shell of late embryogenetic stage of $S$. cf. riqueti removed from brood pouch. Max. height $=2.0 \mathrm{~mm}$. C : Apical detail of B. Width of photograph $=0.39 \mathrm{~mm}$. D : Pathologic sinistral shell of embryonic $S$. cf. riqueti removed from brood pouch. Width of photograph $=$ $0.38 \mathrm{~mm}$. E : Littorina scabra crawling on a mangrove-tree-leaf. Not to scale. F : Shell of adult $L$. scabra. Max. height $=1.6 \mathrm{~cm}$. G : Shell of juvenile L. scabra. Max. height $=4.3 \mathrm{~mm}$. $\mathrm{H}$ : Apical detail of $\mathrm{G}$ showing protoconch with larval hook. Width of photograph $=0.32 \mathrm{~mm}$. I : Adult shell of Septaria cf. tesselata. Max. diameter $=1.8 \mathrm{~cm}$. J : Juvenile shell of $S$. cf. tesselata with posterior protoconch. Max. diameter $=$ $1.4 \mathrm{~mm}$. K : Shell of adult Neritina aff. auriculata. Max. diameter $=1.6 \mathrm{~cm}$. L-N : Adult shells of Clithon oualaniensis exhibit a wide intraspecific range of colour pattern variation. Max. diameter of $\mathrm{L}=8.5 \mathrm{~mm}$. 
fasciatus are included above. $M$. pulchellus revealed a very similar early ontogeny as the latter and probably this is also true for $M$. aff. nucleolus from Cebu.

From the protoconchs it can be concluded that the early ontogenies of $P$. reeveana from Cebu and $P$. scarabaeus from Bali proceed quite similar. $P$. scarabaeus includes single eggs into oval capsules of $0.2 \mathrm{~mm}$ length, which are interconnected by chalazae to form a more or less spiral chain. The capsules are contained in a sac-like gelatinous mass of $1 \mathrm{~mm}$ length. The gastrula stage is reached after 3-4 days of development. Two days later the initial shell cap has been secreted, which subsequently increases rapidly in size. The velum shows a single disc-like lobe, which, however, exhibits two ciliary rings foreshadowing the bilobed condition of the newly hatched veliger. The foot has secreted an operculum and holds two statoliths within the corresponding cysts. During the eighth day of the embryogeny shell and operculum become functional to house the embryo and seal the aperture respectively. Three days later veligers hatch out, which have no eyes, no mantle cavity and only the anlage of a heart.

\section{Discussion}

The distribution of the twenty-six gastropod species, which inhabit the Matutinao River is quite heterogenous. Only five species occur in the upper half of the river where Brotia aff. costula and Tarebia cf. granife$r a$ clearly dominate. The downstream half, i.e. the actual river bed is controlled by neritoideans and the estuarine river banks by ellobiids. This appears to be a clear division between species with lecithotrophic development on one hand and those with a planktotrophic larval phase on the other hand. The planktotrophic fraction colonized the river by introduction of marine larvae to the estuary, settlement of the newly metamorphosed juveniles and subsequent upstream migration by several species.

Lecithotrophic freshwater gastropods are distributed by other means, which, however, may also apply to some of the planktotrophic counterparts. Birds feed by chance on juvenile or even adult gastropods and comparatively thick-shelled and operculate species such as Brotig aff. costula or Tarebia cf. granifera have the potential to escape digestion and leave the avian rectum miles away from their original habitat. This possibility actually exists for all thiarids, Bellamya and those neritoideans, which are not limpet-shaped and thus do not bear a reduced operculum. The extant neritoidean limpets can neither survive digestion within the alimentary tract of a bird, nor are the corresponding egg capsules suitable for transport since they are flat and firmly attached to hard substrate. In the basommatophorans Gyraulus and Radix, the spawn is somewhat gluey and may stick to feathers of water birds and transported this way.

In geological time scales, biogeography is of course greatly controlled by geodynamics. Islands were interconnected e.g. during the Pleistocene when the sea level was much lower. Changing river systems create migration paths through time. Since the Polynesians began to cruise on the Indo-Pacific, the anthropogenetic impact on biogeography also has to be considered. Historical biogeography represents a major avenue of research with regard to answer the question (but see last paragraph), which was raised in the introduction : what determines the distribution of gastropods in a river?

Some generalized conclusions will be presented in the context of focussing on some interesting constellations among gastropod associations in the Matutinao River.

The downstream distribution of Gyraulus and Radix appears to be limited by crustacean predation. Even adults of the gastropods have comparatively thin shells, which can be cracked by the shrimps. This is also true for juveniles of Bellamya, Tarebia and Brotia, which occur in conspiciously low numbers within the lake. Predation is concluded to represent the limiting factor because the abiotic and floristic environment of the artifical lake is suitable for these snails. Further downstream, however, currents are too strong for the basommatophorans as well as for Bellamya, which lives on plankton.

In respect of the transition from section 3 to section 4 the change from a two-species-association to an eight-species-association of gastropods is most obvious. Among the prevailing neritoideans of section 4, the section 3-species of Brotia and Tarebia persist in low numbers and occur sympatric also with Melanoides, which has the same reproductive biology. Thus, do we have an upstream migrating front of neritoideans, an downstream migrating bulk of Tarebia and Brotia or an ecologically balanced zonation ? Considering the geodynamics of Cebu Island (see Introduction), it can be concluded that species with a marine, planktotrophic larva, of which millions come in touch with any uplifting shore, probably had the first opportunity to colonize the developing river. In river systems of the Fiji Islands individuals of Septaria, $\mathrm{Ne}$ ritina or Clithon were found upstream up to $80 \mathrm{~km}$ from the estuary (Haynes 1985). In the Matutinao River, however, the neritoideans stopped after $1 \mathrm{~km}$. Why? 


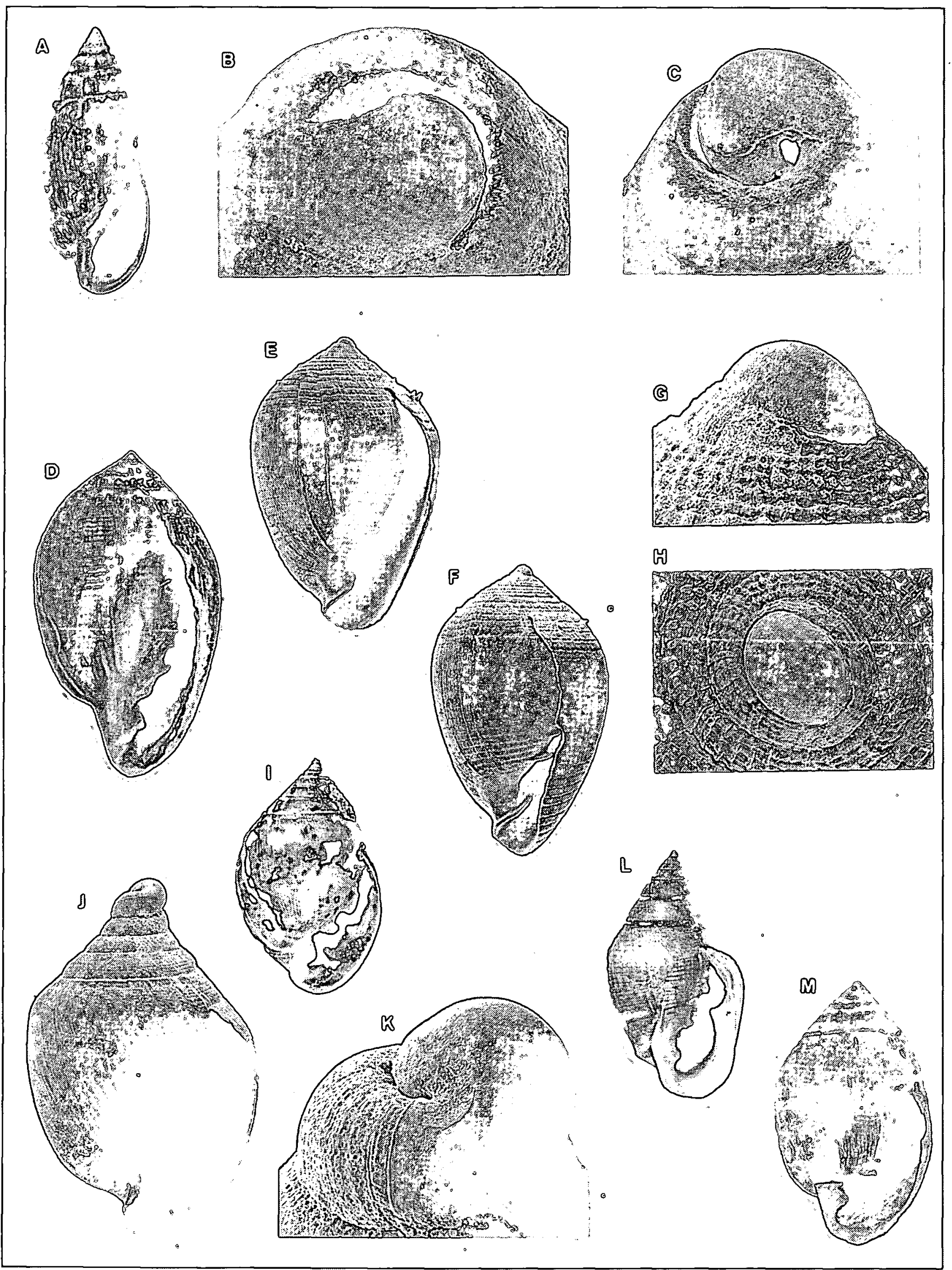

Fig. 8. Gastropods from river section 6. - A : Shell of adult Auriculastra subula. Max. height $=1.4 \mathrm{~cm}$. B : Apex of juvenile shell of $A$. subula. Width of photograph $=0.28 \mathrm{~mm}$. C : Dito, but from the opposite side to show the heterostrophic character of the shell. Width of photograph $=$ $0.31 \mathrm{~mm}$. D : Adult shell of Micromelampus aff. nucleolus. Max. height $=1.0 \mathrm{~cm}$. E : Juvenile shell of $M$. aff. nucleolus. Max. height $=2.9$ $\mathrm{mm}$. F : Lateral view of $\mathrm{E}$ to show the characteristic columellar folds. Max. height $=2.9 \mathrm{~mm}$. G : Protoconch of juvenile $M$. aff. nucleolus. Width of photograph $=0.3 \mathrm{~mm}$. H : Apical view of G. Width of photograph $=0.5 \mathrm{~mm}$. I : Shell of adult Pythia reeveana. Max. height $=1.0 \mathrm{~cm} . \mathrm{J}$ :

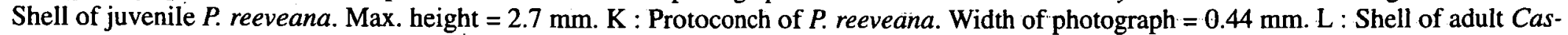
sidula vespertilionis. Max. height $=1.4 \mathrm{~cm}$. M : Shell of adult Melampus cf. fasciatus. Max. height $=2.4 \mathrm{~cm}$. 
The populations of Tarebia and Brotia are very large i.e. in section 3 , and these gastropods browse on algal growth as do the neritoideans. Thus the corresponding gastropods compete with regard to their diet. This competition, however, does not exclude Tarebia and Brotia from section 4 where they coexist with the prevailing neritoideans.

In this context we come to the crucial point. The occurrence of neritoidean juveniles in the uppermost section 4 (see above) has to be explained. It could be speculated that accidental alteration from planktotrophic development to nurse egg feeding proceeded (compare Bandel 1982). This process would lead to the loss of a free-swimming larva. That this possibility actually exists has recently been checked by one of the authors (Riedel, unpublished data for the neogastropod Nassarius reticulatus (LINNÉ, 1758)). Here the impact of UV-radiation actually triggered nurse egg feeding in a species that normally hatches as planktic veliger. The neritoidean juveniles of the uppermost section 4 , however, revealed a protoconch, which was obviously formed by a planktotrophic veliger. In all known cases the loss of a planktotrophic larval phase is correlated with the absence of a larval shell.

Thus, we are forced to conclude that the corresponding neritoideans actually passed through a planktotrophic larval phase, however, not in the marine environment but in freshwater! This would also be one explanation for the findings of Haynes (1985) that Septaria porcellana, which as was documented here is a species with a planktotrophic larval phase, may occur almost $80 \mathrm{~km}$ upstream, a distance much too long to be crept during a single gastropod life. Even if individuals of $S$. porcellana would reach a great age of ten years, they would have to migrate more than twenty meters every day of their life-span to get so far upstream. Such a daily distance is far beyond the organismic potential.

Beside other limiting factors, we propose that the availability of suitable microhabitats within a river system, i.e. zones where the larvae are uncoupled from the main current regime and have a chance to feed on plankton for at least several days, determines the upstream distribution of the corresponding neritoideans.

Consequently, it has to be emphasized that there exist two possibilities within a single species, either to feed on plankton in the marine environment or in freshwater. The occurrence of two different modes of development in one species is termed poecilogony, which sensu strictu cannot be applied here. It is, however, important to visualize that the ecological consequences of the two discussed options of distribution within a single species are comparable to the consequences resulting from poecilogeny.

There is an increase in species number in the river section preceding the estuary. Aside from six neritoidean species, five species of thiarids occurred here. The section was free of Tarebia and Brotia but Melanoides coexisted with Thiara and Stenomelania. We attached some attention to the latter two genera because we found in each genus one species with planktotrophic early ontogeny and a counterpart without a free-swimming larva. The two species of Stenomelania lived sympatric and syntopic, which means that the different modes of development have no effect on ecological zonation of adults (compare Bandel et al. 1997a). This appears to be true also for Thiara.

In respect of phylogeny it is remarkable that the loss of planktotrophy occurred independently at least two times within the Thiaridae. That is particularly of some interest with regard to parthenogenesis, which is assumed by authors - and supported by our investigations to be characteristic of these and other thiarid genera (e.g. Morrison 1954, Brown 1980). The biological species concept cannot be applied to parthenogenetic species where actually every individual represents its own population. If individuals do not interbreed to reproduce, evolution can proceed by transformation only. In conclusion, the evolutionary change from a planktotrophic mode of development to a lecithotrophic early ontogeny can be attributed to transformation unequivocally. It must be considered, however, that sometimes males develop and sexual reproduction may be intercalated.

It has been shown that the special reproductive biology which is characteristic of thiarids correlates with features of the early ontogenetic shell. Bandel \& Kowalke (1997) described a new genus from the Hungarian Eocene, which resembles Tarebia as well as Melanoides. The early ontogenetic shell of this fossil clearly indicates that the embryos developed in a brood pouch. Thus the brood pouch strategy had been established at least 40 million years ago.

Twelve gastropod species were associated in the estuary. This represents the highest number of all sections, which, however, has to be qualified. The five archaeopulmonate species as well as Littorina exhibit amphibious life-style and their ecology is somewhat more related to the river banks and terrestrial environment than to the actual river. From this point of view section 5 reveals the greatest diversity.

The distribution of gastropods in a river is greatly controlled by its environmental setting. The small Matutinao River is colonized by more species than the 
much larger Argao River, which originates almost from the same catchment area, but opens to the Bohol Strait east of Cebu Island. Actually, twenty kilometers of the Argao River revealed less (micro-) habitats than two kilometers of the Matutinao River. We examined more than a dozen river systems on Cebu and found only three more freshwater species, which did not occur in the Matutinao River. Even if we missed one or the other species, it is evident that the overwhelming majority of freshwater gastropod species inhabiting an island, which is about 5000 square kilometers large, is present in a two kilometer long river section.

Even more on the larger biogeographic scale, the different modes of early ontogenetic development planktotrophy and lecithotrophy - play an important role for distributional patterns. These, however, can only be understood at the species level and we are far from resolving the corresponding taxonomic problems.

\section{Acknowledgements}

We would like to express our sincere thanks to F. Wolcke (formerly University of San Carlos, Cebu City) and B. Peters for their logistical help during our stay on Cebu. We are also grateful to $\mathbf{M}$. Cusi (University of San Carlos, Cebu City) for making the facilities of his department available for us, which was essential with regard to the examination of early ontogenetic stages. Ute Heyer (Berlin) and T. Kowalke (Hamburg) helped to document some specimens with the aid of the SEM. Thanks a lot.

\section{References}

Abbott R.T. 1948. - A new genus and species of Philippine Amnicolidae. Nautilus, $61: 75-80$.

Abbott R.T. 1951. - New stenothyrid gastropods from the Philippines. J: Wash. Acad. Sci., 44 : 14-16.

Abbott R.T. 1958. - The gastropod genus Assiminea in the Philippines. Proc. Acad. nat. Sci. Philadelphia, $110: 213-278$.

Ancey C.F: 1898. - Observations on Papuan land and freshwater shells from New Guinea and Western Australia. Proc. linn. Soc. New South Wales, 22 : 771-778.

Bandel K. 1975. - Embryonalgehäuse karibischer Meso- und Neogastropoden (Mollusca). Akademie der Wissenschaften und der Literatur (Mainz) / Abhandlungen der mathematisch-naturwissenschaftlichen Klasse, 1975 (1) : 1-133, 21 pls.

Bandel K. 1982. - Morphologie und Bildung der frühontogenetischen Gehäuse bei conchiferen Mollusken. Facies, 7 : 1-198.

Bandel K. \& Kowalke T. 1997. - Eocene Melanotarebia n.g. and its relation among modern Thiaridae (Caenogastropoda : Cerithioidea). N. Jb. Geol. Paläont, Mh., 1997 (11) : 683-695.

Bandel K, Glaubrecht M. \& Riedel F. 1997a. - On the ontogeny, anatomy, and ecology of the tropical freshwater gastropod Stenomelania (Cerithioidea, Thiaridae). Limnologica, 27 (2) : 239-250.

Bandel K., Riedel F. \& Weikert H. 1997b. - Planktonic gastropod larvae from the Red Sea. Ophelia, 47 (3) : 151-202.

Benthen Jutting W.S.S. van. 1956. - Systematic studies on the nonmarine Mollusca of the Indo-Australian archipelago. 5. Critical revision of the Javanese freshwater gastropods. Treubia, 23 (2) : 259-477.
Benthen Jutting W.S.S. van. 1959. - Catalogue of the non-marine Mollusca of Sumatra and its sattelite islands. Beaufortia, 7 (83) : 41-191.

Bouchet P. 1989. - A review of poecilogony in gastropods. Jour. Moll. Stud., 55 : 57-78.

Brandt R.A.M. 1974. - The non-marine aquatic Mollusca of Thailand. Arch. Molluskenkunde, 105 (1-4) : 1-423.

Brown D.S. 1980. - Freshwater snails of Africa and their medical importance. Taylor \& Francis Ltd, London, 487 p.

Büchsel P. 1991. - Die Morphologie des Küstensaumes von OstCebu (Zentralphilippinen) : Ergebnis pleistozäner Meeresspiegelschwankungen oder tektonischer Bewegungen. Mittl. Geol. Paläont. Inst. Univ. Hamburg, 71 : 243-251.

Burch J.B. 1980. - A guide to the freshwater snails of the Philippines. Malacological Review, 13 : 121-143.

Connolly M. 1939. - A monographic survey of the South African non-marine Mollusca. Ann. S. Afr. Mus., 33 : 1-660.

Davis G.M. 1971. - Systematic studies on Brotia costula episcopalis, first intermediate host of Paragonimus westermani in Malaysia. Proc. Acad. Nat. Sci. Philadelphia, 123 : 53-86.

Dudgeon D. 1989. - Ecological strategies of Hong Kong Thiaridae (Gastropoda : Prosobranchia). Malacol. Rev, 22 : 39-53.

Gardner M.G., Mather P.B., Williamson I. \& Hughes J.M. 1995. The relationship between shell-pattern frequency and microhabitat variation in the intertidal prosobranch, Clithon oualaniensis (Lesson). Malacologia, 36 (1): 97-109.

Glaubrecht M. 1996. - Evolutionsökologie und Systematik am Beispiel von Süß- und Brackwasserschnecken (Mollusca : Caenogastropoda : Cerithioidea) : Ontogenese-Strategien, paläontologische Befunde und historische Zoogeographie. Backhuys Publ., Leiden : $544 \mathrm{p}$.

Gruneberg H. 1976. - Population studies on a polymorphic prosobranch snail (Clithon (Pictoneritina) oualaniensis Lesson). Phil. Trans. Royal Soc. London, B 275 : 385-437.

Harbeck K. 1997. - Die stammesgeschichtliche Entwicklung der Archaeopulmonata. Zoologische Verhandelingen, Leiden, in press.

Haynes A. 1985. - The ecology and local distribution of non-marine aquatic gastropods in Viti Levu, Fiji. Veliger, 28 (2) : 204-210.

Haynes A. 1990. - The number of freshwater gastropods on Pacific islands and the theory of island biogeography. Malacologia, 31 (2) : 237-248.

Haynes A. 1991. - The reproductive patterns of five Fijian species of Septaria (Prosobranchia : Neritidae). Jour. Moll. Stud., 58 : 1320.

Haynes A. 1996. - Reproductive strategies in the freshwater genus Septaria (Neritidae). Malacol. Rev, Suppl. $6: 1-7$.

Hoagland K.E. \& Robertson R. 1988. - An assessment of poecilogony in marine invertebrates : phenomenon or phantasy ? Biological Bulletin, 174 : 109-125.

Morrison J.P.E. 1954. - The relationships of old and new world melanians. Proc. U.S. Nat. Mus., 103 (3325) : 357-394.

Muley E.V. 1978. - Embryology and development of a freshwater prosobranch, Melania scabra. Hydrobiologia, $58: 89-92$.

Pace G.L. 1973. - The freshwater snails of Taiwan (Formosa). Malacol. Rev., Suppl. $1:$ 3-118.

Quadras J.F. \& Moellendorff O.F. 1894. — Diagnoses specierum novarum ex insulis Philippinis. Nachr. Bl. dtsch. malak. Ges., 26 : 81-104, 113-130.

Quadras J.F. \& Moellendorff O.F. 1895. — Diagnoses specierum novarum ex insulis Philippinis. Nachr. Bl. dtsch. malak. Ges., 27 : 73-88, 105-121, 137-149.

Rensch B. 1934. - Süßwasser-Mollusken der Deutschen Limnologischen Sunda-Expedition. Arch. Hydrobiol., Suppl.13 : 3-53. 
Riech E. 1937. - Systematische, anatomische, ökologische und tiergeographische Untersuchungen über die Süßwassermollusken Papuasiens und Melanesiens. Arch. Naturgesch. (N.F.), 6 : 37 153.

Riedel F. 1993. - Early ontogenetic shell formation in some freshwater gastropods and taxonomic implications of the protoconch. Limnologica, 23 (4) : 349-368.

Schneider D.W. \& Frost T.M. 1986. - Massive upstream migrations by a tropical freshwater neritid snail. Hydrobiologia, $137: 153-157$. Springsteen F.J. \& Leobrera F.M. 1986. - Shells of the Philippines. Carfel Seashell Museum, Manila : 377 p.

Starmühlner F. 1976. - Beiträge zur Kenntnis der Süßwasser-Gastropoden pazifischer Inseln. Ann. Naturhist. Mus. Wien, 80 : 473656.
Starmühlner F. 1993. - Ergebnisse der österreichischen SamoaTonga Expedition 1985 des Instituts für Zoologie der Universität Wien : Beiträge zur Kenntnis der Süß- und Brackwasser-Gastropoden der Tonga- und Samoa-Inseln (SW-Pazifik). Ann. Naturhist. Mus. Wien, B 94/95 : 217-306.

Vaught K.C. 1989. - A classification of living Mollusca. American Malacologists Inc. : $189 \mathrm{p}$.

Wenz W. 1938-1944. - Gastropoda. Teil 1. Allgemeiner Teil und Prosobranchia. In : Schindewolf, O.H. (ed.), Handbuch der Paläozoologie, 6 (1) : 1-1639.

Wolcke F. 1991. - Geologische und hydrogeologische Untersuchungen im Gebiet nördlich von Cebu City (Philippinen). Mittl. Geol.-Paläont. Inst. Univ. Hamburg, 71 : 121-241. 